\title{
PEMIKIRAN HUKUM ADAT DJOJODIGOENO DAN RELEVANSINYA KINI
}

\author{
Sulastriyono* dan Sartika Intaning Pradhani** \\ Departemen Hukum Adat, Fakultas Hukum, Universitas Gadjah Mada \\ Jalan Sosio Yustisia No. 1 Bulaksumur, Depok, Sleman, D.I. Yogyakarta 55281
}

Abstract

Djojodigoeno Adat legal thought is started from awareness that the nature of adat law is law. Adat law is the contrary of written law and it is a legal reality. Adat law as original law of Indonesia is the material of Indonesia national law formulation. Sociology and ethnography empirical legal research are tools to find adat law from its source of law. The purpose of adat law finding is to construct Indonesia state law which reflects national identity according to Indonesia socialism. In this current situation, adat law study gives more attention to rights of indigenous peoples and adoption of adat law in legislation; therefore, it is far from Djojodigoeno's expectation.

Keywords: thought, adat law, djojodigoeno

\section{Intisari}

Pemikiran hukum adat Djojodigoeno berangkat dari kesadaran bahwa hakikat hukum adat adalah hukum. Hukum adat adalah lawan dari hukum tertulis dan merupakan realitas hukum. Hukum adat sebagai hukum asli Indonesia menjadi material bagi terbentuknya hukum nasional Indonesia. Penelitian hukum lapangan pada sumber hukum adat secara sosiologi dan etnografi adalah cara untuk menemukan hukum adat. Tujuan dari penemuan hukum adat adalah untuk membentuk hukum negara Indonesia yang mencerminkan kepribadian nasional berdasarkan sosialisme Indonesia. Saat ini kajian hukum adat fokus pada hak-hak masyarakat hukum adat dan adopsi hukum adat dalam peraturan; sehingga semakin jauh dari harapan Djojodigoeno.

Kata Kunci: pemikiran, hukum adat, djojodigoeno

\section{Pokok Muatan}

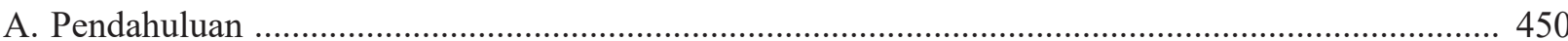

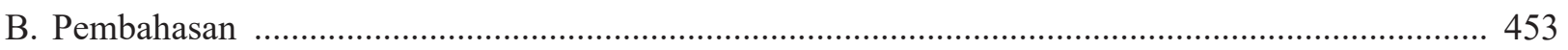

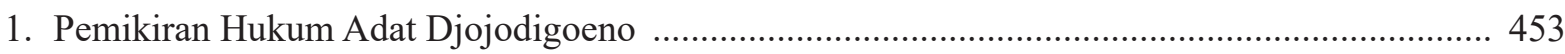

2. Relevansi Hukum Adat Djojodigoeno dalam Kajian Hukum Adat Saat Ini ............................... 459

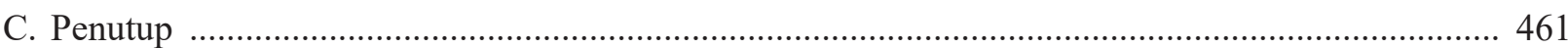

\footnotetext{
* Alamat korespondensi: sulastriyono@mail.ugm.ac.id.
}

**Alamat korespondensi: sartika@mail.ugm.ac.id. 


\section{A. Pendahuluan}

Pemikiran tentang hukum adat sebagai pengetahuan bersifat dinamis karena terus berkembang menuju kesempurnaan. ${ }^{1}$ Hukum adat sebagai pengetahuan empiris mula-mula diperkenalkan oleh Wilken. ${ }^{2}$ Meskipun Wilken tidak menyebutkan secara eksplisit kata hukum adat, pada tahun 1891, Wilken berpendapat bahwa hubungan antara kebiasaan rakyat dan agama rakyat selalu berarti hukum rakyat pribumi yang kadangkadang bagian-bagiannya diubah sedikit oleh unsur Islam atau Hindu. ${ }^{3}$ Kemudian, Liefrinck melakukan penelitian lapangan untuk menjelaskan hukum tanah pribumi, pajak bumi para raja, dan susunan desa pribumi. ${ }^{4}$

Pada Juli 1891, Pemerintah Hindia Belanda mengirim Snouck Hurgronje, advisor for native affair Hindia Belanda, untuk mempelajari unsur agama dalam situasi politikAceh. ${ }^{5}$ Snouck Hurgronje mengatakan jika ingin mengenal kelembagaan Aceh, maka harus dipelajari sistem politik dan peradilan, dan kehidupan keluarga sebagai subsistem. ${ }^{6}$ Jejakjejak penguasaan di Aceh dapat ditemukan dalam satu atau dua pangeran yang berkuasa, Islam yang berupaya untuk memberikan pengaruh, dan yang paling penting adalah berlakunya hukum adat masyarakat pribumi.?
Snouck Hurgronje berpendapat bahwa dalam standar peradaban ras Melayu, hukum yang paling penting bukan hukum yang ditulis, tetapi yang ditemukan dalam ekspresi, kadang-kadang dalam pepatah dan selalu dalam kejadian nyata seharihari yang menggambarkan pemahaman umum. ${ }^{8} \mathrm{Di}$ Aceh, ahli hukum dan ahli agama terlatih dalam doktrin bahwa adat (hukum kebiasaan) dan hukõm (hukum agama) harus berjalan berdampingan dalam negara. ${ }^{9}$ Meskipun demikian, konflik kadang terjadi antara penguasa Muslim yang mempertahankan adat berdasarkan petunjuk Tuhan dan pemuka Muslim yang menjelaskan hukõm. ${ }^{10}$

Menurut Van Vollenhoven, Snouck Hurgronje tidak hanya menemukan hubungan antara hukum agama dan adat, tetapi juga memperkenalkan istilah hukum adat untuk menunjukkan adat yang berakibat hukum, berbeda dengan kebiasaan yang tidak mempunyai arti hukum. ${ }^{11}$ Dalam The Achehnese, Snouck Hurgronje tidak secara tegas menjelaskan bahwa hukum adat adalah adat yang berakibat hukum, tetapi ia memberikan contoh adat yang berakibat hukum dan adat yang tidak mempunyai arti hukum.

Adat yang berakibat hukum dijelaskan antara lain dalam hubungan perkawinan dimana kekayaan

Menurut Syampadzi Nurroh, pengetahuan adalah hasil tahu manusia atas kerjasama antara subjek yang mengetahui dan objek yang diketahui. Pengetahuan bersifat dinamis dalam artian terus berkembang menuju kesempurnaan. Syampadzi Nurroh, 2017, "Studi Kasus: Telaah Buku Filsafat Ilmu (Sebuah Penganter Populer) oleh Jujun S. Suriasumantri”, Assignment paper of Philosophy of Geography Science, Doctoral Program, Graduate School of Envorinment Science, Universitas Gadjah Mada, Yogyakarta, hlm. 19.

Djojodigoeno mengatakan bahwa etnologi dan etnografi adalah ilmu pengetahuan pendukung untuk mempelajari hukum adat. Wilken adalah ahli etnologi yang merupakan pioner dalam pembelajaran Hukum Adat. Lihat M.M. Djojodigoeno, 1950(a), Adat Law in Indonesia, MCMLI Jajasan Pembangunan, Djakarta, hlm. 12.

Lihat Verspreide genschriften I 1912, hlm. 622 dalam C. Van Volenhoven, 1987, Penemuan Hukum Adat, Cetakan Ke II, Penerbit Djambatan, Jakarta, hlm. 130-131.

4 Hasil penelitian hukum tanah pribumi disusun dalam laporan susulan tentang hak-hak atas tanak yang tidak diolah di Bali Utara pada tahun 1889. Hasil penelitian mengenai pajak bumi para raja diterbitkan dalam IG tahun 1886 dan tahun 1887 dalam karangan tentang de rijstcultuur op Bali (pembudidayaan Padi di Bali). Hasil penelitian tentang susunan desa pribumi dicantumkan dalam karya Bijdrage tot de kennis van het eiland Bali (Sumbangan Pengetahuan tentang Pulau Bali, TBG 33, 1890. Ibid., hlm. 135-136.

C. Snouck Hurgronje, 1906, The Achehnese Vol. I., translated b A.W.S. O’Sullivan, Late E.J. Brill, Leyden, hlm. v.

Ibid., hlm. 15-16.

Ibid., hlm. 16

Ibid., hlm. 11.

Ketika hukum agama tidak mengatur, adat menjadi rujukan, tetapi dalam kenyataanya, adat mengatur lebih banyak hal daripada hukõm. Ada kesatuan yang tidak terpisahkan dan kerjasama yang sangat dibutuhkan antara hukum agama dan adat. Hubungan antara adat dan hukum agama dianalogikan sebagai hubungan antara nyonya dan budak. Adat sebagai nyonya dan hukum agama sebagai budak yang setia dimana hukum agama secara sukarela subordinatif terhadap adat; sehingga tidak ada pencarian kemelekatan diantara keduanya. Ibid., hlm. 14 ; 153.

Ibid., hlm. 14.

11 C. Van Volenhoven, 1987, Op.cit., hlm. 142. Menurut Van Vollenhoven, ketika berbicara tentang adat, masyarakat Hindia Belanda tidak pernah atau jarang sekali memasukkan unsur hukum agama yang tidak mengakar pada hukum tanah yang telah berlaku secara turun temurun. Unsur agama dibedakan dari adat dengan merujuk pada istilah khusus, seperti agama di Jawa, hukõm di Aceh dan Gayo, dan hukum agama di Sumatera bagian selatan. Lihat J. F. Holleman (Ed.), 1981, Van Vollenhoven on Indonesian Adat Law, KITLV, Leiden, hlm. 4. 
yang diperoleh atas kerja suami dan istri dibagi dua diantara keduanya. ${ }^{12}$ Adat yang tidak berakibat hukum digambarkan dalam pantangan yang tidak boleh dilakukan oleh wanita hamil, seperti dilarang duduk di atas tangga pintu masuk rumah karena dipercaya dapat mempersulit proses persalinan. ${ }^{13}$ Selain itu, menurut hukum Muhammad ada perintah melakukan ritual salat 5 waktu, namun dalam praktik sembahyang orang Aceh kala itu hanya dilakukan pada waktu-waktu tertentu saja sepanjang tahun. ${ }^{14}$

Untuk menjelaskan hukum yang berlaku bagi masyarakat pribumi, Wilken dan Snouck Hurgronje mempertimbangkan faktor kebiasaan dan agama. Pendapat Wilken dan Snouck Hurgronje merupakan kritik terhadap teori receptio in complexu yang diperkenalkan oleh Van Den Berg bahwa masyarakat Hindia Belanda, khususnya Jawa dan Madura, adalah umat Islam, maka hukum yang berlaku bargi mereka adalah Hukum Islam. ${ }^{15}$ Konkretisasi dari pendapat Van Der Berg adalah Staatsblad 1882 Nomor 152 sebagai dasar pembentukan Pengadilan Agama dan Pasal 134 ayat (2) Indische Staatsregeling yang mengatur bahwa perselisihan perdata antarsesama penduduk inlander atau penduduk yang dipersamakan dengan mereka diputus oleh kepala agama atau kepala adat menurut undangundang agamanya atau adat aslinya.

Berdasarkan Staatsblad 1929 Nomor 221, Pasal 134 ayat (2) Indische Staatsregeling diubah dan lebih condong pada teori receptio yang diperkenalkan oleh Snouck Hurgronje. Snouck
Hurgronje mengatakan bahwa Hukum Islam baru mempunyai kekuatan hukum jika dikehendaki dan diterima oleh hukum adat. ${ }^{16}$ Pasal 134 ayat (2) Indische Staatsregeling kemudian berbunyi dalam hal terjadi sengketa perkara perdata antarsesama orang Islam akan diselesaikan oleh hakim agama Islam apabila hukum adat menghendakinya dan sejauh tidak ditentukan lain oleh suatu ordonannsi. ${ }^{17}$

Menurut Van Vollenhoven, mempelajari hukum di Hindia Belanda bagaikan masuk ke dunia baru. ${ }^{18}$ Hukum yang dipahami di Negeri Belanda adalah hukum sebagai suatu himpunan peraturan yang dikodifikasikan; yang secara lahiriah dibedakan dari peraturan moral, kebijaksaan, estetika; yang secara batiniah sebagai keseluruhan yang hampir lengkap dan serasi. ${ }^{19}$ Sedangkan di Hindia Belanda, hanya sebagian kecil hukum yang dikodifikasikan; perubahan hukum terjadi secara bebas dan tidak disadari; sehingga bagi ahli hukum yang berpegang teguh pada undang-undang, keseluruhan hukum di Hindia Belanda adalah suatu kesimpangsiuran..$^{20}$

Van Vollenhoven mengatakan bahwa tidak ada dalam perbendaharaan kata orang pribumi yang dapat menjelaskan kata hukum secara objektif sebagaimana dalam pikiran para sarjana hukum. ${ }^{21}$ Oleh karena itu, Van Vollenhoven merasa perlu untuk mengusahakan kepastian tertentu dalam peristilahan hukum yang berlaku bagi masyarakat Hindia Belanda untuk menghindari salah pengertian. ${ }^{22}$ Laporan Awal Dutch Lower House menyarankan untuk menggunakan istilah customary

\footnotetext{
C. Snouck Hurgronje, 1906, The Achehnese Vol. I., Loc.cit., hlm. 366. Ibid., hlm. 372-373.

C. Snouck Hurgronje, 1906, The Achehnese Vol. II.,translated b A.W.S. O’Sullivan, Late E.J. Brill, Leyden, hlm. 304.

Abdul Rachmad Budiono, 2003, Peradilan Agama dan Hukum Islam di Indonesia, Bayumedia Publishing, Jakarta, hlm. 3 sebagaimana dikutip oleh Pristiwiyanto, "Staatsblad 1882 Nomor 152 Tonggak Sejarah Berdirinya Pengadilan Agama", Jurnal Fikroh Vol. 8 No. 1 Juli 2014, hlm. 10.

16 Taufiq Hamami, 2003, Kedudukan dan Eksistensi Peradilan Agama dalam Sistem Tata Hukum di Indonesia, Bandung, PT Alumni, hlm. 19 sebagaimana dikutip oleh Nurhasanah, 2017, Analisis tentang Teori Landasan Rumusan Kompetensi Pengadilan Agama, Skripsi, Fakultas Hukum Universitas Sriwijaya, Palembang, hlm. 9.

17 Abdullah Tri Wahyudi, 2004, Peradilan Agama di Indonesia, Yogyakarta, Pustaka Pelajar, hlm. 8 dalam Ibid., hlm. 10.

18 Van Vollenhoven secara langsung berkenalan dengan soal-soal yang berkenaan dengan Hindia Belanda pada 1898 saat ia meninggalkan Universitas Leiden dan bekerja di departement van kolonien yang dipimpin oleh Minister Cremer. Lihat Cornelis Van Vollenhoven, 2013, Orang Indonesia dan Tanahnya, Sleman, STPN Press bekerja sama dengan Sajogyo Institute, Tanah Air Beta, dan Perkumpulan HuMa, hlm. 171. Lihat juga J. F. Holleman (Ed.), Loc.cit., hlm. 1.

9 C. Van Vollenhoven, 1981, Orientasi dalam Hukum Adat Indonesia, KITLV dan Djambatan, Jakarta, hlm. 1 dan lihat J. F. Holleman (Ed.), ibid. C. Van Vollenhoven, 1981, Ibid., hlm. 1-2 dan lihat J. F. Holleman (Ed.), Ibid. C. Van Vollenhoven, 1981, Ibid., hlm. 7 dan lihat J. F. Holleman (Ed.), Ibid., hlm. 4. C. Van Vollenhoven, 1981, Ibid., hlm. 8 dan lihat J. F. Holleman (Ed.), Ibid., hlm. 3.
} 
law (hukum kebiasaan). ${ }^{23}$ Van Vollenhoven merasa hukum kebiasaan bukan istilah yang tepat karena banyak bagian dari hukum masyarakat pribumi dan timur asing tidak dikodifikasi dan tidak berdasarkan pada kebiasaan, tetapi berdasarkan peraturan atau dokumen tertulis. ${ }^{24}$

Van Vollenhoven kemudian merujuk pada temuan Snouck Hurgronje terhadap kata adatrecht (Adat Law atau Hukum Adat), sebagai adat yang mempunyai akibat hukum. ${ }^{25}$ Van Vollenhoven menegaskan bahwa istilah Hukum Adat berbeda dari adat sopan santun karena dalam hukum adat, pelanggaran terhadap adat ada sanksi yang dapat dipaksakan. ${ }^{26}$ Adanya sanksi yang mengandung paksaan inilah yang membuat adat menjadi hukum adat.

Van Vollenhoven membedakan hukum adat dari indigenous law; dan native law. Hukum adat adalah indigenous law yang dipengaruhi oleh unsur agama. ${ }^{27}$ Lingkup indigenous law lebih sempit dari hukum adat karena indigenous law hanya merupakan hukum adat tanpa pengaruh elemen agama. Native law adalah hukum adat (hukum yang tidak dikodifikasi) dan hukum yang dikodifikasi yang berlaku bagi masyarakat pribumi, termasuk Kitab Undang-Undang Hukum Pidana dan Kitab Undang-Undang Hukum Acara. ${ }^{28}$ Lingkup native law lebih luas dari hukum adat karena mencakup hukum adat, termasuk di dalamnya indigenous law yang dipengaruhi oleh unsur agama; dan hukum kodifikasi yang berlaku bagi masyarakat pribumi.

Berbeda dari pendapat Van Vollenhoven tentang hukum, Ter Haar mengatakan bahwa hukum adalah apa yang diputuskan sebagai hukum oleh pejabat-pejabat masyarakat yang bertugas menetapkan keputusan tentang bagaimana hukum berlaku. $^{29}$ Berdasarkan hal tersebut, Ter Haar menjelaskan hukum adat yang berlaku dan kaidahkaidah tertulis yang berlaku adalah keputusankeputusan yang diambil oleh penghulu rakyat baik keputusan kongkrit maupun keputusan untuk perkara-perkara yang sama. ${ }^{30}$ Keputusan tersebut menunjukkan adanya kaidah hukum yang berlaku dalam masyarakat, yaitu hukum sebagai manifestasi dari nilai yang hidup dalam masyarakat; sekaligus hukum yang timbul dari anekaragam gejala sosial masyarakat. ${ }^{31}$

Menurut Van Vollenhoven, untuk berguna bagi tanah air dan bangsa, hukum Indonesia harus mencari jalan sendiri; jangan mencoba mengikuti hukum dan pengetahuan hukum di negeri Belanda. ${ }^{32}$ Djojodigoeno adalah salah satu sarjana hukum yang berusaha untuk menemukan jati diri hukum Indonesia. Menurut Ter Haar, Djojodigoeno adalah sarjana hukum Hindia Belanda yang pada tahun 1940 membahas tentang sistem hukum adat, khususnya

\footnotetext{
J. F. Holleman (Ed.), Ibid., hlm. 3.

24 Ibid., hlm. 3-4. Lingkup hukum adat bukan hanya hukum kebiasaan atau hukum yang tidak dikodifikasikan, tetapi juga peraturan-peraturan resmi atau ketentuan-ketentuan tertulis; peraturan-peraturan desa; maklumat-maklumat raja; peraturan-peraturan mengenai hukum Islam; dan hukum kekaisaran Cina. Lihat C. Van Vollenhoven, 1981, Orientasi dalam Hukum Adat Indonesia, Op.cit., hlm. 5.

25 C. Van Vollenhoven, 1981, ibid., hlm. 7. Lihat juga C. Snouck Hurgronje, 1906, The Achehnese Vol. I., Loc.cit., hlm. 16.

26 C. Van Vollenhoven, 1981, ibid., hlm. 9-10. Lihat J. F. Holleman (Ed.), Op. cit.., hlm. 6. Sanksi yang dapat dipaksakan sebagai satu karakter penting dari hukum juga disampaikan oleh Sudikno Mertokusumo. Hukum berasal dari luar diri manusia yang memaksa dan masyarakat secara resmi diberi kuasa untuk memberikan sanksi atau hukuman. Lihat Sudikno Mertokusumo, 2008, Mengenal Hukum Suatu Pengantar, Cetakan Ke-IV, Liberty, Yogyakarta, hlm. 13.

Ter Haar, 1979, Asas-Asas dan Susunan Hukum Adat, Diterjemahkan oleh K. Ng. Soebakti Poesponoto, Pradnya Paramita, Jakarta, hlm. 275. Penghulu rakyat adalah pendukung-pendukung kekuasaan, pembesar masyarakat/pejabat. Menurut Ter Haar, penghulu rakyat yang bertugas memberi keputusan harus benar-benar sadar akan tanggung jawabnya sebagai pembentuk hukum. Fungsi dari penghulu rakyat adalah untuk menyampaikan kaidah yang berlaku dalam perkara kongkrit maupun perkara-perkara yang sama atau bersangkutan. Sebagaimana hakim, penghulu rakyat dalam memberikan keputusan untuk perkara yang sama perlu memperhatikan keputusan-keputusan terdahulu yang bersifat istimewa, yaitu tepat betul (presiesering) dan dirumuskan (formulering), untuk memberikan sumbangan pengertian terhadap apa yang seharusnya berlaku (substantive law). Ibid. Pendapat Ter Haar tentang hukum adat yang berlaku dipengaruhi oleh penemuan hukum dalam tradisi Common Law. Common Law tumbuh melalui akumulasi dari keputusan-keputusan yang menjadi precedent (keputusan istimewa). Kasus-kasus adalah bagian dari pengalaman bersama yang dipergunakan untuk membentuk nalar hukum, tetapi bukan untuk membentuk hukum yang tidak dapat diubah. Lihat H. Patrick Glenn, 2004, Legal Traditions of the World Sustainable Diversity in Law Second Edition, Oxford University Press Inc., New York, hlm. 250.

31 Ter Haar, Loc.cit.

${ }^{32}$ Verspreide geschriften, jilid I, hlm. 125 sebagaimana dikutip oleh Cornelis Van Vollenhoven, 2013, Op.cit., hlm. 178.
} 
Jawa Tengah. ${ }^{33}$ Djojodigoeno berpendapat bahwa kodifikasi yang telah digunakan sejak zaman Hindia Belanda harus dicabut dan diganti dengan kodifikasi yang baru, kecuali yang telah berlaku dan memperoleh pelaksanaan di masyarakat biarlah berlaku sebagai hukum adat. ${ }^{34}$ Tulisan ini berusaha untuk menggali pemikiran Djojodigoeno tentang hukum adat dan relevansi pemikiran tersebut dengan kajian hukum adat saat ini.

\section{B. Pembahasan}

\section{Pemikiran Hukum Adat Djojodigoeno}

Dalam tulisan ini, pembahasan pemikiran Djojodigoeno tentang hukum adat akan dijabarkan dalam aspek ontologi, aksiologi, epistemologi, dan teleologi. Aspek ontologi membahas perkembangan pemikiran Djojodigoeno dari waktuke waktu tentang hakikat hukum adat. ${ }^{35}$ Aspek aksiologi mengkaji nilai dari hukum adat sebagai satu kesadaran bahwa hukum sebagai ilmu pengetahuan tidak bebas nilai. ${ }^{36}$ Aspek epistemologi mengkaji tentang kebenaran dari ilmu hukum adat melalui pemahasan tentang bagaimana dan dimana pengetahuan hukum adat dapat ditemukan. ${ }^{37}$ Aspek teleologi menerangkan tentang tujuan dari ilmu hukum adat. ${ }^{38}$

\section{a. Aspek Ontologi Hukum Adat Djojodigoeno}

Djojodigoeno pada 5 Agustus 1950 menyampaikan pidato di London tentang Adat Law in Indonesia. Menurut Djojodigoeno, padahakikatnya hukum adat tidak berdasarkan pada prinsip hukum agama. ${ }^{39}$ Hukum adat berakar dalam pikiran dan pandangan hidup masyarakat; dan asasnya dipelajari dalam dan disimpulkan dari kebiasaan, konsep dan ide umum sebagaimana termanifestasi dalam perilaku dan putusan dari ketua dan pejabat lokal atau suku, dan dalam peribahasa dan pepatah populer. ${ }^{40}$ Melalui pendapat ini, Djojodigoeno, Snouck Hurgronje, dan Van Vollenhoven sama-sama membedakan hukum adat dari hukum agama, namun mengakui bahwa ada pengaruh unsur hukum agama terhadap hukum adat.

Pada Hari Ulang Tahun pertama Universitit Negeri Gadjah Mada, 19 Desember 1950, Djojodigoeno berusaha untuk melukiskan watak hukum adat yang

33 Ter Haar, Op.cit., hlm. 293. Nama lengkap Djojodigoeno adalah Muhammad Muhsin Djojodigoeno. Ia lahir di Bantul, 3 Februari 1896 dan meninggal pada 15 Juli 1979. Djojodigoeno adalah guru besar sosiologi dan hukum adat yang pernah menjabat sebagai dekan Fakultas Hukum Universitas Gadjah Mada dan Fakultas Hukum Universitas Airlangga. Djojodigoeno menjabat dekan Fakultas Hukum Universitas Gadjah Mada selama 3 periode, yaitu 1954-1955; 1957-1958; dan 1962-1964; dan dekan Fakultas Hukum Universitas Airlangga pada periode 19531954. Lihat, Abd. Ghofur Anshori (Ed.), 2006, Begawan Hukum Gadjah Mada Sebuah Rekaman Autobiografis, Nuansa Aksara, Yogyakarta, hlm. 66-72.

34 Abd. Ghofur Anshori (Ed.), Op.cit., hlm. 75. Atas pendapatnya ini, Partai Komunis Indonesia merasa Djojodigoeno, kepala kajian hukum adat Fakultas Hukum Universitas Gadjah Mada, dapat menjadi aliansi/sekutu. Djojodigoeno merupakan ahli hukum adat yang telah dilatih oleh Belanda yang dapat mengkombinasikan Paham Jawa dan anti-Barat dengan bangunan filosofi hukum ide Savigny yang romantis. Kemudian, Djojodigoeno menjadi tahanan di penjara Wirogunan Yogyakarta. Lihat David Bourchier, 2015, Illiberal Democracy in Indonesia the Ideology of the Family State, Routledge, New York, hlm. 112. Lihat Hersri Setiawan, 2016, Memoar Pulau Buru I, Cetakan Ke-3, PT Gramedia, Jakarta, hlm. 371-372.

35 Ontologi adalah cabang ilmu filsafat yang menkaji apa hakikat terdalam dari kenyataan. Louis O Kattsoff, 1989, Pengantar Filsafat, Cetakan Ke-IV, Tiara Wacana, Yogyakarta, hlm. 212. Ontologi membicarakan tentang hakikat mendasar keberadaan sesuatu. Abdul Ghofur Anshori, 2009, Filsafat Hukum, Cetakan Ke-II, Gadjah Mada University Press, Yogyakarta, hlm. 1.

36 Aksiologi adalah bagian dari filsafat yang khusus membahas hakikat nilai berkaitan dengan sesuatu. Abdul Ghofur Anshori, Ibid., hlm. 1-2 dan lihat Sartika Intaning Pradhani, "Konsepsi Manusia Indonesia dalam Perspektif Ideologi Hukum Indonesia”, Mimbar Hukum Volume 30, Nomor 1, Februari 2018, hlm. 56.

37 Noeng Muhadjir, 2001, Filsafat Ilmu Positivisme, Postpositivisme, dan Postmodernisme Edisi II, Rake Serasin, Yogyakarta, hlm. 60. Jujun S. Suriasumantri, 1990, Filsafat Ilmu Sebuah Pengantar Populer, Pustaka Sinar Harapan, Jakarta, hlm. 119.

38 Sudjito Atmoredjo, 2016, Ideologi Hukum Indonesia Kajian tentang Pancasila dalam Perspektif Hukum dan Dasar Negara Indonesia, Lingkar Media, Yogyakarta, hlm. 97.

39 Untuk menunjukkan hukum adat tidak berdasarkan prinsip hukum agama, Djojodigoeno memberikan contoh dalam lapangan hukum perkawinan dan hukum waris. Pada prinsipnya masyarakat Indonesia mengikuti prinsip perkawinan monogami. Perkawinan poligami tidak terjadi dan ide tentang hal tersebut menimbulkan kemarahan dan kutukan dari masyarakat. Dalam masyarakat muslim, perkawinan poligami adalah perkawinan pengecualian, namun tetap memicu cemoohan yang ditakuti oleh orang-orang. Dalam masyarakat yang bukan muslim, perkawinan poligami tidak dikenal. Secara umum, hukum waris tidak mengikuti hukum waris Eropa maupun Islam. Hukum waris adat selalu menunjukkan hubungan yang dekat antara organisasi sosial dan kekerabatan dengan hukum privat; sehingga hukum waris yang berlaku di Jawa, Batak, dan Minangkabau berbeda karena organisasi masyarakatnya diatur dalam hukum kekerabatan yang berbeda. M.M. Djojodigoeno, 1950(a), Loc.cit., hlm. 12-17.

$40 \quad$ Ibid. 
dalam sistem hukum barat (Belanda) disebut privaatrecht atau strafrecht. ${ }^{41}$ Menurut Djojodigoeno, hukum adat memandang masyarakat sebagai paguyuban artinya sebagai satu jenis hidup bersama dimana manusia memandang sesamanya sebagai tujuan, bukan berdasarkan kepentingan dan laba-rugi. ${ }^{42}$ Hal ini berbeda dari semangat hukum barat yang memandang masyarakat sebagai patembayan dimana manusia memandang sesama manusia sebagai lantaran, jalan untuk mencapai kepentingan diri sendiri dengan memperhitungkan labarugi. ${ }^{43}$

Oleh karena hukum adat berlaku dalam masyarakat yang bersifat paguyuban, antarsesama anggota masyarakat saling menghargai hubungan damai diantara mereka. Penyelesaian perselisihan dilakukan dengan kerukunan, melalui perdamaian yang kompromis. ${ }^{44}$ Penyelesaian permasalahan tidak berdasarkan benar-salah sebagaimana penyelesaian masalah melalui pengadilan; namun ditujukan untuk tercapainya hubungan damai untuk masa yang akan datang. ${ }^{45}$ Asas keadilan dan kepatutan yang hidup dalam keyakinan masyarakat menjadi sumber hukum karena masyarakat paguyuban percaya bahwa manusia bersedia melaksanakan hukum yang seadil-adilnya dan sepatut-patutnya; sehingga hukum tidak perlu kodifikasi. ${ }^{46}$ Hukum adat tidak perlu dikodifikasi karena bersifat dinamis plastis dan berwujud tidak tertulis. ${ }^{47}$

Berbeda dengan hukum barat yang berlaku dalam masyarakat yang bersifat patembayan, masing-masing anggota masyarakat dipandang sebagai orang yang cerdik dan selalu menguntungkan diri sendiri; sehingga harus dihadapi dengan sikap hatihati/cermat/teliti supaya ia tidak dianiaya/ merasa menderita. ${ }^{48}$ Sebagai orang yang cerdik, keadilan dikalahkan oleh nalar atau rasio; sehingga dibutuhkan hukum yang tegas dan rinci untuk mencapai kepastian hukum. ${ }^{49}$ Itulah mengapa diperlukan kodifikasi secara tegas dan kasuistik/spesifik untuk memuat hukum yang bersifat memaksa. ${ }^{50}$ Sifat dari hukum kodifikasi yang berwujud tertulis adalah kaku dan kuno karena ketika hukum sudah ditetapkan; maka untuk menjamin kepastian hukum, ia tidak dapat berubah.

Pada 21 Juli 1958, Djojodigoeno sebagai pengajar Mata Kuliah Hukum Adat merasa berkewajiban untuk menjelaskan apa yang dimaksud dengan hukum adat. Menurut Djojodigoeno, sebelum menjelaskan apa hukum adat perlu dijelaskan terlebih dahulu

M.M. Djojodigoeno, 1950(b), Menjandra Hukum Adat, Jajasan Fonds Universitit Negeri Gadjah Mada, Jogjakarta, hlm. 3-5.

2 Ibid., hlm. 5. Masyarakat Indonesia adalah socio- dan traditio-bound people; sertiap orang harus bertindak dan berperilaku sebagaimana orang lain, menjadi biasa/pada umumnya. Menjadi berbeda dari yang lain adalah satu hal yang aneh, memalukan, buruk, dan dapat dihukum. Tidak ada ruang bagi kebebasan berkontrak dan kompetisi sebagai perbuatan hukum yang pasti, yang mengandung gugatan yang pasti. M.M. Djojodigoeno, 1950, Adat Law in Indonesia, Op. cit., hlm. 13.

43 M.M. Djojodigoeno, 1950(b), Op.cit., hlm. 6.

44 Ibid. Lihat juga, hlm. 21. Koentjaraningrat, 1979, Kebudayaan Mentalitet dan Pembangunan, Cetakan Ke-VI, PT Gramedia, Jakarta.

45 Jika penyelesaian masalah dilakukan melalui pengadilan, maka penyelesaian masalah tetap dilakukan dengan cara yang adil dan patut. M.M. Djojodigoeno, 1950(b), Loc.cit.

46 Ibid., hlm. 6-8.

47 Hukum adat bersifat dinamis dan selalu modern karena hakim ketika menegakkan hukum adat dapat mengambil keputusan yang berlainan dalam masalah hukum yang sama pada waktu yang berlainan berdasarkan pertimbangan perbedaan asas hukum yang berkembang menurut perkembangan masyarakat. Hukum bersifat dinamis ketika hukum dapat mengikuti perkembangan masyarakat yang pasti membutuhkan perubahan dalam dasar-dasar hukum sepanjang jalan sejarahnya untuk mencapai keadilan. Hukum adat bersifat plastis karena hukum adat berpangkal dari asas-asas hukum yang menentukan hukum dalam garis besarnya; sehingga untuk menegakkan keadilan hakim dapat memutus dua masalah hukum yang berada dalam satu pola (sama) secara berbeda karena masing-masing berdasarkan berbagai peristiwa yang berbeda. Ibid., hlm. 8-10.

48 Ibid., hlm. 7.

49 Tegas artinya disampaikan melalui perkataan yang terang untuk menghindai perbedaan pengertian dan rinci artinya mengatur dengan teliti segala hal, sampai yang khusus-khusus untuk mencegak perselisihan. Ibid., hlm. 7-8.

50 Asas kepastian hukum yang tercermin dalam hukum yang dikodifikasi menjadi sumber hukum bagi masyarakat yang bersifat patembayan. 
apa hukum karena hukum adat itu hukum per definitionem. ${ }^{51}$ Pendapat ini berbeda dari apa yang disampaikan oleh Van Vollenhoven yang berangkat dari adat untuk mengabstraksi hukum adat. Van Vollenhoven menangkap adat sebagai realitas sosial kemudian mengkonstruksi hukum adat sebagai adat yang memiliki sanksi yang dapat dipaksakan.

Djojodigoeno berpendapat bahwa hukum adalah suatu karya dari seluruh rakyat dalam suatu hubungan pamrih yang masih perlu pelaksanaan..$^{52}$ Sifat dari karya tersebut adalah paugeran (norma) yang membatasi tingkah laku dan perbuatan orang dalam hubungan pamrih. ${ }^{53}$ Berdasarkan pengertian tersebut, Djojodigoeno menyebutkan ada 6 ciri-ciri hukum. Pertama, hukum positif, hukum yang berlaku pada waktu tertentu, di dalam suatu masyarakat tertentu kini dan di sini adalah ius constituendum, bukan ius constitutum. ${ }^{54}$ Kedua, hukum adalah karya masyarakat tertentu. ${ }^{55}$ Ketiga, hukum adalah paugeran (norma) tingkah laku dan perbuatan dalam hubungan pamrih; sehingga dapat dipaksakan. ${ }^{56}$ Keempat, tujuan dari hukum sebagai karya adalah untuk (a) tata; (b) keadilan; dan (c) kesejahteraan masyarakat. ${ }^{57}$ Kelima, secara resmi, perundang-undangan adalah sumber hukum yang utama; sehingga yurispruensi dan adat kebiasaan tidak boleh bertentangan dengan perundang-undangan. ${ }^{58}$ Keenam, hukum adalah objek dari yurisprudensi dan sosiologi hukum, namun keduanya mendekati hukum dengan cara yang berbeda. ${ }^{59}$

Berdasarkan ciri-ciri hukum di atas, Djojodigoeno berpendapat bahwa dari penelusuran yang telah dilakukan terhadap hukum, tidak ditemukan hakikat dari hukum adat, kecuali dalam yurisprudensi yang bersifat dinamis plastis karena dapat mengikuti perkembangan masyarakat secara umum dan individu dalam masing-masing kasus. ${ }^{60}$ Untuk mengetahui hakikat hukum adat, Djojodigoeno kemudian merujuk pada realitas hukum Bangsa Indonesia bahwa pertama, kekuasaan Hindia Belanda memisahkan peradilan pidana dan perdata; kedua hukum pidana dan perdata memiliki kodifikasi masing-masing; dan ketiga, dalam hukum perdata berlaku tiga sistem (1) kodifikasi untuk Eropa dan Tionghoa; (2)

51 M.M. Djojodigoeno, 1961(a), Reorientasi Hukum dan Hukum Adat, Cetakan Ke-II, PT Penerbitan Universitas, Jogjakarta, hlm. 5.

52 Karya yang sudah dilaksanakan misalnya rakyat telah mengambil keputusan, hakim telah menentukan hukuman, dan kepala negara telah menentukan tindakan. Ibid., hlm. 15. Pada 1969, Djojodigoeno menyimpulkan bahwa hukum adalah suatu proses pengugeran yang senantiasa membaharui diri oleh suatu masyarakat akan tingkah laku dan perbuatan para anggotanya yang menentukan untuk perhubungan pamrih mereka; langsung oleh masyarakat sendiri atau melalui pejabat-pejabat kewibawaannya, yang berarti mendasari dan memelihara tata, keadilan dan kesejahteraan bersama. Pendapat ini dimuat dalam majalah Nijmegen dikutip dari Fakultas Hukum Universitas Gadjah Mada, "Seminar Pendidikan Hukum Reorientasi Pendidikan Hukum pada Fakultas Hukum Universitas Gadjah Mada dalam Akselerasi Pembangunan Negara Republik Indonesia", Laporan, Fakultas Hukum Universitas Gadjah Mada, Yogyakarta, hlm. 303. Sudjito mengatakan bahwa sampai saat ini (2016) pengajaran ilmu hukum Indonesia masih terus melanjutkan pengetahuan yang tumbuh dan berkembang dari zaman pra-Republik Indonesia, yaitu zaman Hindia Belanda. Lihat Sudjito Atmoredjo, Op.cit., hlm. 40.

53 Ibid.

54 Menurut Djojodigoeno, ius constitutum merupakan hukum yang lampau karena telah dilaksanakan/dinyatakan. Ada dua kategori ius constitutum, yaitu hukum yang dilaksanakan oleh kekuasaan negara, eksekutif, legislatif, dan yudikatif; dan hukum yang diselenggarakan oleh rakyat sendiri. Ibid., hlm. 15.

55 Ibid., hlm. 17.

56 Ibid.

57 Pedoman pelaksanaan karya hukum harus berpedoman pada (1) asas-asas dan peragaan hukum di waktu yang lampau yang merupakan ukuran statik; (2) keadaan masyarakat pada masa sekarang yang merupakan ukuran dinamis; dan (3) individualitas masing-masing kasus yang merupakan ukuran plastis. Ibid., hlm. 18-20.

58 Ibid., hlm. 20.

59 Yurusprudensi mendekati hukum sebagai suatu karya yang seharusnya, tidak sebagai fakta yang sudah terjadi; sehingga masih perlu pelaksanaan. Sosiologi hukum mendeskripsikan hukum sebagai realitas. Ibid., hlm. 26. Lihat juga Rikardo Simarmata, 2008, "Penelitian Hukum: dari Monodisipliner ke Interdisipliner", makalah bahan pengembangan diskusi dengan staf pengajar Fakultas Hukum, Universitas Balikpapan, hlm. 1-5.

60 Ibid., hlm. 28. Dalam pendapat ini, Djojodigoeno terlihat mendukung pendapat Ter Haar tentang teori keputusan, namun sebenarnya tidak. Di tahun 1960 melalui tulisan Harapan Hukum Adat Indonesia Djojodigoeno secara tegas Djojodigoeno menolak pendapat Ter Haar. Lihat Djojodigoeno, 1960, Harapan Hukum Adat Indonesia, Badan Penerbit Gadjah Mada, Jogjakarta, hlm. 9. 
sistem hukum kodifikasi dan sistem hukum adat untuk golongan Timur Asing bukan Tionghoa; dan (3) sistem hukum adat bagi golongan pribumi. ${ }^{61}$

Djojodigoeno mengemukakan bahwa pada prinsipnya pelaksanaan hukum dalam sistem hukum kodifikasi dan dalam sistem hukum adat sama saja karena berdasarkan ukuran (1) asas-asas dan peragaan hukum dalam waktu lampau; (2) keadaan masyarakat; dan (3) individualitas masing-masing kasus. ${ }^{62}$ Namun demikian, ada perbedaan penting yang perlu diperhatikan. Kodifikasi sebagai peraturan yang harus dipatuhi dapat memaksa berlakunya norma yang bertentangan dengan gaya kehidupan masyarakat sehari-hari. ${ }^{63}$ Hakim dalam sistem hukum kodifikasi harus menerapkan norma-norma hukum kodifikasi dalam suatu perkara, sedangkan hakim dalam sistem hukum adat lebih merdeka untuk menyimpang dari asas-asas hukum dan peragaan hukum pada waktu lampau (sumber hukum) ${ }^{64}$ Hakim dalam sistem hukum adat dapat memasukkan atau mengeluarkan suatu perbuatan dalam dan dari lingkungan perhubungan pamrih karena deskripsi asasasas dan sumber hukum di suatu daerah harus selalu diragukan. ${ }^{65}$ Keragu-raguan itu timbul karena mungkin deskripsi tersebut tidak tepat atau mungkin deskripsi tersebut telah menjadi usang, sehingga tidak tepat lagi. ${ }^{66}$

Djojodigoeno pada Dies Natalis

Universitas Gadjah Mada ke XI

menyampaikan bahwa hukum adat sebagai hukum yang tidak tertulis merupakan lawan dari hukum peraturan; dan hukum adat Indonesia adalah bahan hukum asli Indonesia yang dilawankan dengan bahan hukum asing yang termuat dalam berbagai kodifikasi yang saat itu (hingga saat ini) berlaku di Indonesia, seperti Wetboek van Strafrecht (WvS/Kitab Undang-Undang Hukum Pidana), Wetboek van Koophandel (WvK/ Kitab UndangUndang Hukum Dagang), dan Burgerlijk Wetboek (BW/ Kitab Undang-Undang Hukum Perdata). ${ }^{67}$ Dalam pengertian ini, Djojodigoeno tidak mempermasalahkan pengaruh agama terhadap hukum adat, namun tegas membedakan hukum adat sebagai lawan dari hukum peraturan; dan merupakan bahan hukum Indonesia asli.

\section{b. Aspek Aksiologi Hukum Adat Djojodigoeno}

Proklamasi kemerdekaan Indonesia yang berkumandang pada 17 Agustus 1945 merupakan titik awal pembentukan tata hukum Indonesia untuk menggantikan tata hukum Belanda yang berlaku di Indonesia. Untuk mengkonstruksi tatanan hukum Indonesia yang merdeka, dibutuhkan material. Hukum adat sebagai bahan hukum asli Indonesia adalah material yang dapat membentuk hukum negara Indonesia. Djojodigoeno mengatakan bahwa hukum adat bumiputra dalam arti substansial sebagai realitas hukum yang hidup di kalangan rakyat

Ibid., hlm. 28-29.

Ibid., hlm. 29.

Ibid.

Hakim dalam hukum adat diharapkan tidak hanya berintelektualitas tinggi, tetapi juga orang budiman yang luas dan dalam pengetahuannya, luhur kesusilaannya, dan halus perasaanya. Hakim yang menegakkan hukum adat berkerja dalam masyarakat yang bersifat paguyuban; sehingga hakim mempunyai kewenangan untuk bertindak tidak hanya mengadili dengan nalarnya, tetapi juga mendamaikan kedua belah pihak yang harus diadili; dan mempunyai kebebasan dalam mengatur jalannya peradilan. Hakim yang mengadili berdasarkan hukum adat perlu menyelaraskan (menjumbuhkan) antara pengadilan dan keadilan dengan cara (1) menyelidiki secara saksama asas-asas hukum yang terkandung dalam jiwa rakyat; (2) melafalkan dan menerapkan asas-asas hukum dalam satu masalah: (3) bertanggungjawab atas kebenaran penerapan asas hukum. Hakim dapat memberikan putusan yang menyimpang dari tuntutan penggugat apabila peristiwanya telah terang; apabila hukumnya telah terang; dan apabila penerapan hukum secara tegas dan tepat dapat menimbulkan kezaliman. M.M. Djojodigoeno, 1950(b), Op.cit., hlm. 11-12.

65 Ibid., hlm. 30.

66 Djojodigoene memberikan contoh bahwa deskripsi tentang hukum adat yang berlaku di Jawa Tengah dipublikasikan pad tahun 1940 berdasarkan penelitian tahun 1935-1938. Jika deskripsi tersebut tepat pada tahun 1940, belum tentu masih tepat pada tahun 1958. Ibid.

67 M.M. Djojodigoeno, 1960, Op.cit., hlm. 1. 
Indonesia harus menjadi dasar bagi hukum negara. ${ }^{68}$ Hukum adat bumiputra dalam arti substansial adalah bahan hukum yang nyatanyata hidup di kalangan rakyat golongan bumiputra dan saat itu (sampai saat ini) belum dikofidikasikan. ${ }^{69}$

Indonesia seharusnya menggunakan sistem hukum adat, bukan sistem hukum kodifikasi. $^{70}$ Sistem hukum adat perlu diterapkan dalam hukum negara karena hukum adat merupakan bahan hukum asli Indonesia atau realitas hukum atas berbagai prinsip yang nyata berlaku di dalam suatu masyarakat. ${ }^{71}$ Sayangnya, hingga saat ini hukum Indonesia masih menerapkan hukum Hindia Belanda, misalnya dalam lapangan hukum pidana, hukum kodifikasi Hindia Belanda sebagai realitas hukum pidana Belanda sejak tahun 1880 masih diterapkan di Indonesia.

\section{c. Epistemologi Hukum Adat Menurut Djojodigoeno}

Ada yang beranggapan bahwa hukum adat Indonesia bersifat kuno dan beku. Djojodigoeno mengatakan bahwa jika anggapan itu benar, maka penyebabnya adalah masyarakat Indonesia masih bersifat beku dan mempertahankan keyakinan kuno. ${ }^{72}$ Kodifikasi hukum bukan merupakan jawaban untuk mengubah masyarakat yang beku menjadi masyarakat yang dinamis. ${ }^{73}$ Penyelenggaraan pendidikan rakyat adalah satu jalan untuk mengubah masyarakat yang bersifat beku menjadi dinamis. ${ }^{74}$

Sayangnya, sarjana hukum Indonesia tidak menghargai realitas hukum nasional Indonesia dan malah lebih mendewakan hukum romawi karena para sarjana hukum itu (masih) dididik dan diajar dalam suasana kolonial; sehingga dalam hati kecilnya beranggapan bahwa kodifikasi Belanda adalah kebenaran tertinggi dari kebijaksanaan hukum. ${ }^{75}$ Para sarjana hukum itu tidak dapat menangkap bahwa masing-masing hukum positif mempunyai individualitas sendirisendiri sesuai dengan keadaan masyarakat. ${ }^{76}$ Bahkan, para sarjana hukum berpendapat bahwa hukum adat adalah hukum yang lapuk, kuno, usang, dan harus diganti dengan hukum modern tanpa sadar bahwa negara modern, seperti negara Anglo Saxon, juga menggunakan adat sebagai sistem hukum. ${ }^{77}$

Djojodigoeno berpendapat bahwa hukum adat adalah realitas hukum dimana prinsip-prinsip yang berlaku dalam hubungan pamrih masyarakat ditemukan. ${ }^{78}$ Berdasarkan pendapat ini, Djojodigoeno menolak pendapat Logeman yang mengatakan bahwa hukum adat bukanlah hukum yang bersumber dari adat kebiasaan. Djojodigoeno

68 Lihat ibid., hlm. 15. Lihat juga Khudzaifah Dimyati, 2010, Teorisasi Hukum: Studi tentang Perkembangan Pemikiran Hukum di Indonesia Tahun 1945-1990, Genta Publishing, Yogyakarta, hlm. 170.

69 M.M. Djojodigoeno, 1960, Op.cit., hlm. 15.

70 Negara-negara yang menghendaki kodifikasi hukum kerakyatan dan hukum pidana adalah negara Eropa Kontinental, sedangkan negara yang tidak menghendaki kodifikasi atau menggunakan sistem hukum adat adalah Negara Anglo Saxon. Dalam sistem hukum adat berlaku juga hukum peraturan (statute law) di samping hukum tidak tertulis (common law). Ibid., hlm. 2.

71 Ibid., hlm. 3. Lihat juga Sudjito, 2014, Ilmu Hukum Holistik Studi Untuk Memahami Kompleksitas dan Pengaturan Pengelolaan Irigasi, Gadjah Mada University Press, Yogyakarta, hlm. 3.

2 M.M. Djojodigoeno, 1960, Op.cit., hlm. 13.

Ibid., hlm. 13.

Ibid., hlm. 14

75 Bahkan hingga tahun 1975 kurikulum Fakultas Hukum Universitas Gadjah Mada pada hakikatnya masih sama dengan kurikulum Rechtshogeshool yang berpangkal dari pengertian bahwa hukum sebagai suatu rangkaian norma, bukan suatu karya manusia yang terus menerus dilaksanakan dan senantiasa memperbaharui diri yang berwujud paugeran dari masyarakat. Suatu rangkaian norma hanyalah bekas dari karya tersebut. Lihat Fakultas Hukum Universitas Gadjah Mada, Op.cit., hlm. 293.

76 Menurut Djojodigoeno, para sarjana hukum tidak dapat menangkap perkataan Gaston May bahwa hukum itu berlainan untuk berbagai bangsa sesuai dengan kebutuhannya; sesuai dengan corak ragam pelaksanaan perhubungan pamrihnya; dan bahwa bangsa hukum itu berada dalam perubahan hukum terus menerus mengikuti perubahan zaman. Ibid., hlm. 8.

77 M.M. Djojodigoeno, 1960, Op.cit., hlm. 9-10.

$78 \quad$ Ibid., hlm. 3. 
juga menolak pendapat Ter Haar tentang hukum adat adalah keputusan fungsionaris adat karena keputusan hanyalah bekas dari hukum. Menurut Djojodigoeno, pendapat Logemann dan Ter Haar tentang hukum adat tidak mempunyai werdi (makna) karena arti dari hukum adat tidak pernah masuk dalam kesadaran mereka. ${ }^{79}$

Menurut Djojodigoeno, Universitas Gadjah Mada sebagai universitas nasional yang berkewajiban untuk membuang sifat kolonial perlu melakukan penelitian secara saksama terhadap hukum adat sebagai realitas hukum. Para sarjana hukum perlu melakukan penelitian empiris terhadap realitas hukum kerakyatan (perdata), hukum negara, hukum pidana, dan hukum acara tidak hanya menggunakan ilmu hukum, tetapi ilmu sosiologi dan etnografi. ${ }^{80}$ Sebagai hukum yang tidak bersumber kepada peraturan, hukum adat dapat ditemukan dalam (1) pernyataan kekuasaan pemerintah, yaitu (a) putusan pejabat eksekutif dan yudikatif; (b) perjanjian internasional dan penyataan perang; dan (2) pernyataan kekuasaan rakyat, yaitu (a) perbuatan rakyat dalam menyelenggaraan dan melaksanakan hubungan pamrih yang mungkin menebal menjadi adat kebiasaan; (b) keputusan rakyat dalam lembaga kemasyarakatan; (c) pemberontakan terhadap penguasa yang ada. ${ }^{81}$ Berdasarkan hal tersebut, Djojodigoeno menolak pendapat Van Vollenhoven tentang hukum adat adalah hukum yang tidak bersumber pada peraturan yang dibuat oleh Pemerintah Hindia Belanda. ${ }^{82}$ Van Vollenhoven mengatakan bahwa peraturan desa, peraturan raja-raja bumiputra, dan peraturan hukum fiqh sebagai sumber hukum adat. ${ }^{83}$ Menurut Djojodigoeno, hukum adat tidak bersumber dari hukum agama; peraturan raja yang dimuat dalam rijksblad dan peraturan desa yang ditulis rapi masuk dalam kategori peraturan; sehingga ketiganya bukan merupakan sumber hukum adat. $^{84}$

\section{d. Aspek Teleologi Hukum Adat Djojodigoeno}

Tujuan dari kemerdekaan kebangsaan Indonesia adalah untuk melindungi segenap bangsa Indonesia dan seluruh tumpah darah Indonesia; untuk memajukan kesejahteraan umum; mencerdaskan kehidupan bangsa; dan ikut melaksanakan ketertiban dunia yang berdasarkan kemerdekaan, perdamaian abadi dan keadilan sosial. Untuk mencapai tujuan tersebut, Indonesia sebagai suatu negara modern tidak hanya sematamata negara hukum, namun juga negara kesejahteraan. Hukum merupakan instrumen untuk mencapai kesejahteraan tersebut. Menurut Djojodigoeno, tujuan dari hukum sebagai karya masyarakat tertentu dalam zaman modern ini adalah (1) tata; (2) yang adil dalam tingkah laku dan perbuatan orang dalam hubungan pamrih; dan (3) kesejahteraan masyarakat itu sendiri yang

79 Djojodigoeno berpendapat bahwa pendapat Logeman dan Ter Haar tentang hukum adat tidak mempunyai makna karena pendapat tersebut tidak berangkat dari kesadaran bahwa hukum adat adalah bahan hukum atau realia hukum dari berbagai prinsip yang berlaku dalam hubungan pamrih masyarakat. Ibid., hlm. 9.

80 Djojodigoeno memberikan contoh hukum kerakyatan, khususnya hukum dagang membutuhkan penelitian lapangan yang dapat menjelaskan bagaimana pedagang besar menyelenggarakan dan melaksanakan transaksi; apakah ada perbedaan dalam hak transaksi antara orang golongan bumiputra, Tionghoa, dan Eropa. Meskipun pengetahuan tentang realitas hukum pidana asli Indonesia masih sedikit, Djojodigoeno menyampaikan bahwa ada beberapa asas hukum pidana yang telah diketahui, yaitu (1) tidak adanya pemisahan prosedur antara peradilan perdata dan peradilan pidana; (2) terbatasnya jenis reaksi yang dapat diambil oleh hakim dalam memutus kasus pidana menurut WvS; (3) beda-beda pelafalan suatu perbuatan kejahatan; dan (4) perbedaan penilaian terhadal suatu perbuatan kejahatan. Ibid., hlm. 10-17.

81 M.M. Djojodigoeno, 1958, Asas-Asas Hukum Adat, Jajasan Badan Penerbit Gadjah Mada, Jogjakarta, hlm. 7-8. Pada tahun 1961, Djojodigoeno tidak menyebutkan hukum internasional sebagai sumber hukum adat. Lihat, Djojodiguno, 1961(b), Asas-Asas Hukum Adat Kuliah Tahun 1960/1961 Djilid 1, Jajasan Badan Penerbit Gadjah Mada, Jogjakarta, hlm. 10.

82 Djojodiguno, 1961(b), Ibid., hlm. 8.

83 Ibid., hlm. 7. Lihat juga M.M. Djojodigoeno, 1958, Ibid., hlm. 8.

84 Ibid., hlm. 8. Lihat juga M.M. Djojodigoeno, 1958, Op.cit., hlm. 7. 
menjadi dasarnya. ${ }^{85}$

Pancasila sebagai dasar filsafat hukum Indonesia merupakan rujukan untuk menyelesaikan permasalahan negara dan tertib hukum Indonesia. ${ }^{86}$ Pendidikan yang berdasarkan Pancasila, khususnya pendidikan hukum, adalah salah satu upaya untuk mencapai tujuan tersebut. Universitas Gadjah Mada merupakan salah satu penyelenggara pendidikan. Jati diri Universitas Gadjah Mada adalah Universitas Pancasila dan Universitas Sosialis Indonesia. ${ }^{87}$ Sebagai Universitas Sosialis Indonesia, rencana pengajaran khususnya di lingkungan Universitas Gadjah Mada harus berubah dengan tujuan untuk menyesuaikan dengan sosialisme Indonesia pada khususnya dan menemukan kembali kepribadian nasional pada umumnya. ${ }^{88}$ Tujuan dari penemuan hukum adat melalui penelitian lapangan adalah untuk menemukan bahan hukum nasional asli Indonesia yang dapat membangun jati diri manusia Indonesia yang seyogyanya hidup berdasarkan sosialisme Indonesia dengan asas-asas sebagai berikut: ${ }^{89}$

1)

Sosialisme Indonesia tidak berpangkal kepada invidualisme ataupunkolektivisme, melainkan menghendaki kesejahteraan dari kebulatan manusia-masyarakatkebudayaan;

2) Sosialisme Indonesia tetap menjamin kepribadian masingmasing anggota masyarakat dan menolak otoriter;

3) Sosialisme Indonesia menjamin keadilan sosial, tidak hanya atas organisasi masyarakat, tetapi juga adat sikap jika yang mengutamakan hubungan guyub.

\section{Relevansi Hukum Adat Djojodigoeno dalam Kajian Hukum Adat Saat Ini}

Saat ini yang dimaksud dalam tulisan ini, dimaknai sebagai waktu pasca reformasi 1998 yang ditandai dengan amandemen UUD 1945. ${ }^{90}$ Pasca reformasi, hukum adat dibicarakan dalam diskursus masyarakat hukum adat atau masyarakat adat sebagai subyek hukum penyandang hak-hak, termasuk di dalamnya hak-hak tradisional. Pada tahun 2006, Bosko menulis tentang Hak-Hak Masyarakat Adat dalam Konteks Pengelolaan Sumber Daya Alam. Dalam bukunya, Bosko mengatakan bahwa proyekproyek sumber daya alam tidak hanya menyebabkan diambilnya tanah masyarakat adat, tetapi juga mengakibatkan dampak buruk bagi kehidupan, budaya, lingkungan, dan hak-hak masyarakat adat. ${ }^{91}$ Hak-Hak masyarakat adat tersebut antara lain, hak untuk tidak didiskriminasi, hak atas tanah dan sumber daya alam dan hak-hak terkait, hak atas lingkungan hidup yang sehat dan hak untuk memberikan persetujuan (right to consent). ${ }^{92}$

Mahkamah Konstitusi juga memberikan sumbangan pemikiran tentang hukum adat melalui penemuan hukum tentang pengakuan dan penghormatan negara terhadap hak-hak masyarakat

85 M.M. Djojodigoeno, 1961 (b), Op.cit., hlm. 14.

86 Notonegoro, 1951, Pantjasila Dasar Filsafat Negara Republik Indonesia, pidato pada promosi honoris causa dalam ilmu hukum dilakukan oleh Senat Universitit Negeri Gadjah Mada, hlm. 31. Notonagoro, 1957, Berita Pikiran Ilmiah tentang Kemungkinan Djalan Keluar dari Kesulitan Mengenai Pantjasila sebagai Dasar Negara Republik Indonesia, Universitas Gadjah Mada, Jogjakarta, hlm. 57.

87 Djojodigoeno, 1961(c), Asas-Asas Hukum Adat Kuliah Tahun 1960/1961 Djilid 2, Jajasan Badan Penerbit Gadjah Mada, Jogjakarta, hlm. 86. Berdasarkan Pasal 8 Peraturan Pemerintah Nomor 67 Tahun 2013 tentang Statuta Universitas Gadjah Mada, sosialis Indonesia tidak lagi menjadi jati diri Universitas Gadjah Mada. Jati diri Universitas Gadjah Mada adalah universitas nasional; perjuangan; Pancasila; kerakyatan; dan pusat kebudayaan.

88 Ibid., hlm. 98 .

89 Ibid., hlm. 109. Lihat juga Sudjito, et al., 2013, Jati Diri Manusia Indonesia dalam Perspektif Pembentukan Karakter Bangsa, Gadjah Mada University Press, Yogyakarta, hlm. 87-89.

90 Pasca amandemen, Pasal 18(B) ayat (2) Undang-Undang Dasar Negara Republik Indonesia Tahun 1945 mengatur bahwa Negara mengakui dan menghormati kesatuan-kesatuan masyarakat hukum adat beserta hak-hak tradisionalnya sepanjang masih hidup dan sesuai dengan perkembangan masyarakat dan prinsip Negara Kesatuan Republik Indonesia, yang diatur dalam undang-undang.

91 Rafael Edy Bosko, 2006, Hak-Hak Masyarakat Adat dalam Konteks Pengelolaan Sumber Daya Alam, ELSAM, Jakarta, hlm 171.

92 Ibid. 
hukum adat. ${ }^{93}$ Menurut Rikardo Simarmata dan Bernadus Steni, pengakuan hukum terhadap Masyarakat Hukum Adat tidak lagi menjawab eksistensi Masyarakat Hukum Adat, namun menjelaskan pada bidang hukum mana Masyarakat Hukum Adat mempunyai kecakapan hukum. ${ }^{94}$ Kecakapan hukum subjek hukum Masyarakat Hukum Adat dapat diakui melalui tiga jalur, yaitu jalur desa adat, hak komunal, dan hutan adat.

Pada 23 April 2013, Pusat Kajian Hukum Adat Djojodigoeno Fakultas Hukum Universitas Gadjah Mada mengadakan diskusi "Pengaturan Hak-Hak Masyarakat Adat dalam berbagai RUU". Diskusi tersebut dilatarbelakangi oleh pembahasan beberapa Rancangan Undang-Undang (RUU) yang akan mengatur tentang hak-hak masyarakat adat. Dalam diskusi tersebut, Sumardjono menyampaikan bahwa RUU tentang Masyarakat Hukum Adat yang diusulkan oleh Dewan Perwakilan Rakyat, RUU tentang Perlindungan Hak Masyarakat Hukum Adat yang diusulkan oleh Dewan Perwakilan Daerah, dan RUU tentang Masyarakat Adat yang diusulkan oleh Aliansi Masyarakat Adat Nusantara memiliki titik temu, yaitu bahwa ketiganya sama-sama hendak mengatur tentang hak publik-privat Masyarakat Hukum Adat untuk memberikan kepastian hukum atas hak yang mereka sandang selaku subjek hukum..$^{95}$
Pada tahun 2014, Sumardjono menulis buku dengan "Semangat Konstitusi dan Alokasi yang Adil atas Sumberaya Alam" yang menjelaskan antara lain tentang prinsip dasar pengakuan, penghormatan, dan perlindangan Masyarakat Hukum Adat, khususny Masyarakat Hukum Adat di Papua. ${ }^{96}$ Pada 2018, Sumardjono menulis buku "Regulasi Pertanahan dan Semangat Keadilan Agraria" yang antara lain untuk menjelaskan perlunya ada penegasan penggunaan istilah hak komunal yang diatur dalam Peraturan Menteri Agraria dan Tata Ruang/Kepala Badan Pertanahan Nasional No. 9 Tahun 2015 tentang Tata Cara Penetapan Hak Komunal atas Tanah Masyarakat Hukum Adat. ${ }^{97}$

Akhir-akhir ini, pembahasan Rancangan Undang-Undang Hukum Pidana (RUU HP) membuka ruang diskusi sejauh mana akomodasi negara terhadap hukum yang hidup dalam masyarakat (hukum adat) dapat dilakukan. Sasmitha mengatakan bahwa pengecualian asas legalitas berpotensi mencabut hukum adat dari koteks berlakunya pada masyarakat pengemban dan menanamkannya pada konteks yang sangat luas di level negara dan di sisi lain, komunitas pengemban hukum adat tidak memiliki cukup kekuatan untuk berinteraksi secara seimbang dengan institusi penegak hukum. ${ }^{98}$ Sasmitha menjelaskan bahwa menggunakan hukum adat sebagai dasar

93 Putusan Mahkamah Konstitusi Nomor 35/PUU-X/2012 tertanggal 16 Mei 2013 menegaskan bahwa masyarakat hukum adat secara konstitutional diakui dan dihormati sebagai penyandang hak dan dapat dibebani kewajiban. Keberadaan hutan adat dalam kesatuannya dengan wilayah hak ulayat dari suatu masyarakat hukum adat adalah konsekuensi pengakuan terhadap hukum adat sebagai living law yang sudah berlangsung sejak zaman Hindia Belanda hingga sekarang. Putusan Mahkamah Konstitusi Nomor 3/PUUVIII/2010 tertanggal 16 Juni 2011 membatalkan Hak Pengusahaan Perairan Pesisir (HP3) karena pemberian HP3 akan potensial mengancam posisi masyarakat adat dan nelayan tradisional yang menggantungkan hidupnya secara turun-temurun dari sumber daya yang ada pada perairan pesisir dan pulau-pulau kecil.

94 Rikardo Simarmata, et al., 2017, Masyarakat Hukum Adat sebagai Subyek Hukum: Kecakapan Hukum Masyarakat Hukum Adat dalam Lapangan Hukum Privat dan Publik, the Samdhana Institute, Bogor, hlm. 169

95 Hak tersebut dapat diakui melalui identifikasi baik oleh Panitia yang dibentuk oleh Pemerintah atau self-identification oleh Masyarakat Hukum Adat itu sendiri. Setelah identifikasi, akan dilanjutkan dengan proses verifikasi, pengumuman, validasi, dan penetapan. Diskusi ini juga mendiskusikan tentang RUU Pertanahan yang semakin mengkerdilkan Masyarakat Hukum Adat karena peralihan hak atas tanah ulayat hanya dapat dilakukan setelah tanah tersebut dilepaskan dari statusnya sebagai tanah ulayat menjadi tanah negara. Setelah menjadi tanah negara, tanah tersebut dapat dialihkan haknya menjadi Hak Guna Usaha. Setelah habisnya Hak Guna Usaha, Masyarakat Hukum Adat tidak dapat kembali menguasai tanah tersebut karena tanah itu sudah dilepaskan.

96 Menurut Sumardjono, meskipun masyarakat hukum adat diakui dan dilindungi secara konstitusional, pola pikir yuridis-formal semata tidak sesuai untuk diterapkan dalam memahami konstruksi hukum dan budaya terkait tanah ulayat di Papua. Maria S.W. Sumardjono, 2014, Semangat Konstitusi dan Alokasi yang Adil atas Sumberdaya Alam, Fakultas Hukum Universitas Gadjah Mada, Yogyakarta, hlm. $109-110$.

97 Maria S.W. Sumardjono, 2018, Regulasi Pertanahan dan Semangat Keadilan Agraria, STPN Press, Sleman, hlm. 48.

98 Tody Sasmitha, "Hukum Adat sebagai Konsep yang Bergerak: Catatan terhadap Pluralisme Hukum Indonesia dan Pembentukan RUU Hukum Pidana", makalah, disampaikan dalam Semiloka "MewujudkanPembaharuanHukumPidanamelalui R-KUHP yang Berkeadilan, DemokratisdanResponsifpada Perkembangan Tindak Pidana” yang diadakan oleh Koalisi Perempuan Indonesia padaKamis 15 Maret 2018 di Hotel A One, Jakarta, hlm. 1. Pasal 2 ayat (1) dan (2) RUU HP mengatur bahwa "[...] tidak mengurangi berlakunya hukum yang hidup dalam masyarakat yang menentukan bahwa seseorang patut dipidana walaupun perbuatan tersebut tidak diatur dalam peraturan perundang- 
pemidanaan tidak sama dengan mempertimbangkan hukum adat dan mekanisme adat dalam proses menjatuhkan pidana karena hukum adat diposisikan hanya sebagai bahan bagi pembentukan hukum negara. ${ }^{99}$

Pada 29 April 2018, Pusat Studi Hukum Adat Djojodigoeno mengadakan diskusi "Hukum Adat sebagai Pengecualian Asas Legalitas pada RUU HP”. Dalam diskusi tersebut, Marcus Priyo Gunarto, Guru Besar Hukum Pidana Universitas Gadjah Mada, menyampaikan bahwa dalam draf RUU HP, tidak ada terminologi hukum adat, namun semua guru besar pidana yang ikut dalam pembahasan draf RUU HP mengakui bahwa ada delik pidana adat, sedangkan untuk menentukan hukum yang hidup dalam masyarakat ada beberapa pendapat. Marcus Priyo Gunarto dengan merujuk pada pendapat Djojodiguno yang mengatakan bahwa hukum adat bersifat dinamis dan merupakan kaedah yang tidak tertulis, sehingga ketika menjadi tertulis, maka kaedah tersebut menjadi layon (mati) berpendapat bahwa RUU HP perlu mengakui delik pidana adat, namun tidak perlu membuat kompilasi pidana adat karena akan membatasi sifat dinamis hukum adat itu sendiri.

Mendukung pendapat Marcus Priyo Gunarto, Agus Sudaryanto, berpendapat bahwa hukum adat adalah living law, yaitu hukum yang tidak dikodifikasi dan tidak perlu dikompilasi. Dalam RUU HP hukum yang hidup dalam masyarakat dibatasi dengan beberapa ketentuan, antara lain berlaku dalam tempat hukum itu hidup dan sepanjang tidak diatur dalam undang-undang ini; tidak bertentangan dengan nilai-nilai yang terkandung dalam Pancasia; tidak bertentangan dengan UUD NRI Tahun 1945; tidak bertentangan dengan hak asasi manusia; dan tidak bertentangan dengan asas-asas hukum umum yang diakui masyarakat beradab. Berdasarkan hal tersebut, maka sesungguhnya hukum yang hidup dalam masyarat memiliki lingkup yang lebih luas dari hukum adat. Marcus Priyo Gunarto menambahkan bahwa luasnya makna dari hukum yang hidup dalam masyarakat menimbulkan kekhawatiran tentang kemungkinan hukum tersebut digunakan sebagai alat represif hukum yang hidup sebagai dasar pemidanaan.

\section{Penutup}

Pemikiran hukum adat Djojodigoeno dapat dijelaskan dalam aspek ontologi, aksiologi, epistemologi, dan teleologi. Pada hakikatnya hukum adat adalah hukum. Hukum adalah proses penormaan hubungan pamrih oleh masyarakat sendiri atau pejabat yang berwenang yang secara terus-menerus diperbarui. Hukum adat sebagai realitas hukum adalah bahan hukum asli Indonesia yang menjadi material bagi terbentuknya hukum nasional Indonesia. Untuk mengetahui hukum adat perlu dilakukan penelitian lapangan dengan menggunakan tidak hanya metode hukum, tetapi juga sosiologi dan etnogafi. Tujuan dari penemuan hukum adat adalah untuk membentuk hukum nasional Indonesia yang mencerminkan kepribadian nasional berdasarkan sosialisme Indonesia. Kajian hukum adat saat ini membahas tentang hak-hak masyarakat hukum adat dan adopsi hukum adat dalam peraturan. Kajian hukum hari ini secara umum semakin jauh dari harapan Djojodigoeno karena hanya fokus pada penerapan asas-asas hukum positif dalam kasus-kasus konkret.

undangan" dan "hukum yang hidup dalam masyarakat [...] berlaku dalam tempat hukum itu hidup dan sepanjang tidak diatur dalam UndangUndang ini dan sesuai dengan nilai-nilai yang terkandung dalam Pancasila, UUD NRI Tahun 1945, hak asasi manusia, dan asas-asas hukum umum yang diakui masyarakat beradab".

99 Ibid. Lebih lanjut Sasmitha menambahkan bahwa penggunaan "hukum yang hidup" dalam legislasi Indonesia telah disalahartikan. "Hukum Adat sebagai Pengecualian Asas Legalitas pada RUU HP' untuk mencari kejelasan apa yang dimaksud dengan hukum yang hidup dalam masyarakat. 


\section{DAFTAR PUSTAKA}

\section{A. Buku}

Anshori, Abd. Ghofur, (Ed.), 2006, Begawan Hukum Gadjah Mada Sebuah Rekaman Autobiografis, Nuansa Aksara, Yogyakarta. , 2009, Filsafat Hukum, Cetakan

Ke-II, Gadjah Mada University Press, Yogyakarta.

Atmoredjo, Sudjito, 2016, Ideologi Hukum Indonesia Kajian tentang Pancasila dalam Perspektif Hukum dan Dasar Negara Indonesia, Lingkar Media, Yogyakarta.

Bosko, Rafael Edy, 2006, Hak-Hak Masyarakat Adat dalam Konteks Pengelolaan Sumber Daya Alam, ELSAM, Jakarta.

Bourchier, David 2015, Illiberal Democracy in Indonesia the Ideology of the Family State, Routledge, New York.

Dimyati, Khudzaifah, 2010, Teorisasi Hukum: Studi tentang Perkembangan Pemikiran Hukum di Indonesia Tahun 1945-1990, Genta Publishing, Yogyakarta.

Djojodigoeno, M.M., 1950(a), Adat Law in Indonesia, MCMLI Jajasan Pembangunan, Djakarta.

1950(b), Menjandra Hukum Adat, Jajasan Fonds Universitit Negeri Gadjah Mada, Jogjakarta. , 1958, Asas-Asas Hukum Adat, Jajasan Badan Penerbit Gadjah Mada, Jogjakarta. 1960, Harapan Hukum Adat Indonesia, Badan Penerbit Gadjah Mada. Jogjakarta, , 1961(a), Reorientasi Hukum dan Hukum Adat, Cetakan Ke-II, PT Penerbitan Universitas, Jogjakarta. 1961(b), Asas-Asas Hukum Adat Kuliah Tahun 1960/1961 Djilid 2, Jajasan Badan Penerbit Gadjah Mada, Jogjakarta. , 1961(c), Asas-Asas Hukum Adat Kuliah Tahun 1960/1961 Djilid 1, Jajasan Badan Penerbit Gadjah Mada, Jogjakarta.

Glenn, H. Patrick, 2004, Legal Traditions of the
World Sustainable Diversity in Law Second Edition, Oxford University Press Inc., New York.

Haar, Ter, 1979, Asas-Asas dan Susunan Hukum Adat, Diterjemahkan oleh K. Ng. Soebakti Poesponoto, Pradnya Paramita, Jakarta.

Holleman, J. F. (Ed.), 1981, Van Vollenhoven on Indonesian Adat Law, KITLV, Leiden.

Hurgronje, C. Snouck 1906, The Achehnese Vol. II., translated b A.W.S. O'Sullivan, Late E.J. Brill, Leyden. 1906, The Achehnese Vol. I., translated b A.W.S. O'Sullivan, Late E.J. Brill, Leyden. Koentjaraningrat, 1979, Kebudayaan Mentalitet dan Pembangunan, Cetakan Ke-VI, PT Gramedia, Jakarta.

Mertokusumo, Sudikno, 2008, Mengenal Hukum Suatu Pengantar, Cetakan Ke-IV, Liberty, Yogyakarta.

Muhadjir, Noeng, 2001, Filsafat Ilmu Positivisme, Postpositivisme, dan Postmodernisme Edisi II, Rake Serasin, Yogyakarta.

Notonagoro, 1951, Pantjasila Dasar Filsafat Negara Republik Indonesia, pidato pada promosi honoris causa dalam ilmu hukum dilakukan oleh Senat Universitit Negeri Gadjah Mada. , 1957, Berita Pikiran Ilmiah tentang Kemungkinan Djalan Keluar dari Kesulitan Mengenai Pantjasila sebagai Dasar Negara Republik Indonesia, Universitas Gadjah Mada, Jogjakarta.

Nurhasanah, 2017, “Analsisi tentang Teori Landasan Rumusan Kompetensi Pengadilan Agama”, Skripsi, Fakultas Hukum Universitas Sriwijaya.

Pradhani, Sartika Intaning, 2018, Konsepsi Manusia Indonesia dalam Perspektif Ideologi Hukum Indonesia, Mimbar Hukum Volume 30, Nomor 1, Februari 2018.

Setiawan, Hersri, 2016, Memoar Pulau Buru I, Cetakan Ke-3, PT Gramedia, Jakarta. 
Simarmata, Rikardo, 2008, "Penelitian Hukum: dari Monodisipliner ke Interdisipliner", makalah bahan pengembangan diskusi dengan staf pengajar Fakultas Hukum, Universitas Balikpapan.

Simarmata, Rikardo, et al., 2017, Masyarakat Hukum Adat sebagai Subyek Hukum: Kecakapan Hukum Masyarakat Hukum Adat dalam Lapangan Hukum Privat dan Publik, the Samdhana Institute, Bogor, hlm. 169.

Sudjito, 2014, Ilmu Hukum Holistik Studi Untuk Memahami Kompleksitas dan Pengaturan Pengelolaan Irigasi, Gadjah Mada University Press, Yogyakarta.

Sudjito, et al., 2013, Jati Diri Manusia Indonesia dalam Perspektif Pembentukan Karakter Bangsa, Gadjah Mada University Press, Yogyakarta.

Sumardjono, Maria S.W., 2014, Semangat Konstitusi dan Alokasi yang Adil atas Sumberdaya Alam, Fakultas Hukum Universitas Gadjah Mada, Yogyakarta. , 2018, Regulasi Pertanahan dan Semangat Keadilan Agraria, STPN Press, Sleman.

Suriasumantri, Jujun S., 1990, Filsafat Ilmu Sebuah Pengantar Populer, Pustaka Sinar Harapan, Jakarta.

Volenhoven, C. Van, 1981, Orientasi dalam Hukum Adat Indonesia, KITLV dan Djambatan, Jakarta.

1987, Penemuan Hukum Adat, Cetakan Ke II, Penerbit Djambatan, Jakarta. ,2013, Orang Indonesia dan Tanahnya, STPN Press bekerja sama dengan Sajogyo Institute, Tanah Air Beta, dan Perkumpulan HuMa, Sleman.

\section{B. Artikel Jurnal}

Pristiwiyanto, "Staatsblad 1882 Nomor 152 Tonggak Sejarah Berdirinya Pengadilan Agama", Jurnal Fikroh, Vol. 8 No. 1 Juli 2014.

\section{Hasil Penelitian/Tugas Akhir}

Nurhasanah, 2017, Analisis tentang Teori Landasan Rumusan Kompetensi Pengadilan Agama, Skripsi, Fakultas Hukum Universitas Sriwijaya, Palembang.

Nurroh, Syampadzi, 2017, "Studi Kasus: Telaah Buku Filsafat Ilmu (Sebuah Penganter Populer) oleh Jujun S. Suriasumantri”, Assignment paper of Philosophy of Geography Science, Doctoral Program, Graduate School of Envorinment Science, Universitas Gadjah Mada, Yogyakarta.

\section{Makalah/Pidato}

Fakultas Hukum Universitas Gadjah Mada, "Seminar Pendidikan Hukum Reorientasi Pendidikan Hukum pada Fakultas Hukum Universitas Gadjah Mada dalam Akselerasi Pembangunan Negara Republik Indonesia", Laporan, Fakultas Hukum Universitas Gadjah Mada, Yogyakarta.

Sasmitha, Tody "Hukum Adat sebagai Konsep yang Bergerak: Catatan terhadap Pluralisme Hukum Indonesia dan Pembentukan RUU Hukum Pidana", makalah, disampaikan dalam Semiloka "Mewujudkan Pembaharuan Hukum Pidana melalui R-KUHP yang Berkeadilan, DemokratisdanResponsifpada Perkembangan Tindak Pidana" yang diadakan oleh Koalisi Perempuan Indonesia padaKamis 15 Maret 2018 di Hotel A One, Jakarta.

\section{E. Peraturan Perundang-Undangan}

Undang-Undang Dasar Negara Republik Indonesia Tahun 1945.

Peraturan Pemerintah Nomor 67 Tahun 2013 tentang Statuta Universitas Gadjah Mada (Lembaran Negara Republik Indonesia Tahun 2013 Nomor 165, Tambahan Lembaran Negara Republik Indonesia Nomor 5454). 
F. Putusan Pengadilan

Putusan Mahkamah Konstitusi Nomor 35/ PUU-X/2012 perihal Pengujian UndangUndang Nomor 41 Tahun 1999 tentang Kehutanan terhadap Undang-Undang Dasar Negara Republik Indonesia Tahun 1945, 16 Mei 2013.
Putusan Mahkamah Konstitusi Nomor 3/ PUUVIII/2010 perihal Pengujian UndangUndang Nomor 27 Tahun 2007 tentang Pengelolaan Wilayah Pesisir dan Pulaupulau Kecil terhadap Undang-Undang Dasar Negara Republik Indonesia Tahun 1945, 16 Juni 2011. 